\title{
Conception Rates Following Breeding at Foal Heat Versus Induced Heat in Postpartum Indigenous Mares
}

\author{
J. S. Mahal*, M. Honparkhe, Ajeet Kumar and Parladh Singh \\ Department of Veterinary Gynaecology and Obstetrics, Guru Angad Dev Veterinary and \\ Animal Sciences University, Ludhiana, India \\ *Corresponding author
}

\section{A B S T R A C T}

\begin{abstract}
The present study was conducted to compare the conception rates following breeding at foal heat versus induced heat in postpartum indigenous mares. Twenty mares with history of normal foaling and expulsion of placenta and occurrence of foal heat between 6-10 days after foaling were included in the study. These mares were subjected to transrectal ultrasonography during foal heat to record uterine oedema, accumulation of fluid and endometrial thickness. These mares were randomly divided into 2 groups $(n=10$ in each).Group I mares were bred naturally during first estrus postpartum (Foal heat) whereas, in group II, breeding during foal heat was skipped. On day 28 postpartum, group II mares received synthetic $\mathrm{PGF}_{2 \alpha}$ (Cloprostinol) @ $500 \mu \mathrm{g}$ followed by covering with fertile stallion on induced estrus twice at $36 \mathrm{hrs}$ interval. Mean \pm SEM uterine oedema grade during foal heat was significantly higher $(\mathrm{P}<0.05)$ as compared to during induced heat $(4.5$ \pm 0.08 vs $2.3 \pm 0.1)$. The endometrial thickness during foal and induced heat was $6.2 \pm 0.1$ $\mathrm{mm}$ and $5.03 \pm 0.16 \mathrm{~mm}$, respectively. The intrauterine fluid accumulation was observed in $70 \%(14 / 20)$ mares during foal heat $(\mathrm{P}<0.05)$ versus only $20 \%(2 / 10)$ during postpartum induced heat. Mean \pm SEM diameter of dominant ovulatory follicle in group I and II were $31.8 \pm 0.75$ and $31.0 \pm 0.55 \mathrm{~mm}$, respectively. The first service conception rate in group I and II was $20 \%$ and $80 \%(\mathrm{P}<0.05)$, respectively. The natural breeding during induced heat yielded higher conception as compared to foal heat breeding which may be attributed to accumulation of intrauterine fluid during foal heat in postpartum mares.
\end{abstract}

\section{Keywords}

Estrus induction, Equine breeding, Foal heat, Mare

Article Info

Accepted:

15 March 2020

Available Online:

10 April 2020

\section{Introduction}

The reproductive management of a mare during foal heat is of prime importance for equine breeders to reduce economic losses during maintenance of mare for next successive estrous cycles. After foaling, the first estrus of mare is generally considered as foal heat which typically ranges from 5-15 days McCue (2010), Macpherson (2012). The basic strategy of breeders which follow concept of breeding at foal heat is to increase production and ensuring a foaling every year. The mares coming to estrus within 6-10 days after foaling have more chances of conception failure and early abortions due to presence of placental debris, fluid and incomplete involution of uterus. Whereas, the mares 
which come to estrus after 10 or more days post foaling comparatively more chances of conception. Dystocia, retained placenta and endometritis further reduce chances of conception during foal heat breeding. Mares generally return to regular cyclicity 21 days after foal heat McCue (2010).

To avoid confusion among breeders about correct time of breeding due to wide variability in onset of foal heat and to reduce chances of conception failure, the concept of breeding during second estrus post foaling (around 30 days), where almost complete involution of uterus and ovarian rebound has been completed, is considered most accurate strategy to avoid all the misconceptions and to enhance reproductive efficiency of mare. Therefore, the objective of the study to compare the conception rates following natural breeding during foal heat and induced heat in postpartum indigenous mares.

\section{Materials and Methods}

The experiment was conducted on 20 Marwari mares aged between 4 to 10 years ( $\mathrm{I}^{\text {st }}$ to $4^{\text {th }}$ Parity) during February to June months of the year. Mares with normal foaling and expulsion of placenta and occurrence of first estrus (foal heat) between 6-10 days were included in the study. These mares were subjected to transrectal ultrasonography (USG) using linear array transducer with 5/7.5 interchangeable frequency (BCF technology) on second day of foal heat to observe uterine fluid accumulation, endometrial thickness, uterine oedema grade Rasmussen et al., (2015) and dominant follicle diameter. Mares were randomly divided into 2 groups. The mares from group I $(n=10)$ were allowed for natural breeding staring at $48 \mathrm{hrs}$ of foal heat followed by second mating at $36 \mathrm{hrs}$ interval. In group II(n $=10$ ) mares the natural breeding during foal heat was skipped. On day 28 postpartum, these mares were administered with synthetic $\mathrm{PGF}_{2 \alpha}$ (Cloprostinol) @ $500 \quad \mu \mathrm{g}$ intramuscularly followed by covering with fertile stallion on induced estrus twice at 36 hrs interval. At induced heat, these mares were again subjected to transrectal ultrasonography to record uterine fluid accumulation, endometrial thickness and uterine oedema grade.

Pregnancy diagnosis in both the groups was done between 21-25 days after last covering through transrectal ultrasonography.

The numerical data regarding uterine oedema grade, endometrial thickness and diameter of dominant follicle are represented as mean \pm SEM, and differences were considered to be significant at $\mathrm{P}<0.05$. The statistical analysis for significance was done using students t-test and chi square test according to the data represented.

\section{Results and Discussion}

The ultrasonographic observations regarding uterine oedema, endometrial thickness, accumulation of excess uterine fluid and diameter of dominant follicleduring foal heat and induced heat is presented in Table 1. During foal heat, the number of mares with the accumulation of excess uterine fluid and uterine oedema grade was significantly higher $(\mathrm{P}<0.05)$ as compared to that during induced estrus. The endometrial thickness was nonsignificantly higher during foal heat as compared to induced heat. The diameter of dominant follicle (Fig. 1) was almost similar during foal and induced heat. The first service conception was significantly lower $(\mathrm{P}<0.05)$ in group I which was bred during foal heat as compared to group II (bred during postpartum induced heat). Admin (2016) reported comparatively higher conception rates (46\%) after breeding during foal heat as compared to present study. 
Table.1 Ultrasonographic observations during foal and induced heat in postpartum indigenous mares

\begin{tabular}{|l|c|c|}
\hline Parameters & $\begin{array}{c}\text { At foal heat } \\
(\mathbf{n = 2 0})\end{array}$ & $\begin{array}{c}\text { At induced heat } \\
(\mathbf{n = 1 0})\end{array}$ \\
\hline Uterine oedema grade ( Fig. 2) & $4.5 \pm 0.08^{*}$ & $2.3 \pm 0.1$ \\
\hline Endometrial thickness (mm) & $6.2 \pm 0.1$ & $5.03 \pm 0.16$ \\
\hline $\begin{array}{l}\text { Number of mares with excess } \\
\text { accumulation of uterine fluid (\%) }\end{array}$ & $14 / 20(70)^{*}$ & $2 / 10(20)$ \\
\hline Diameter of dominant follicle (mm) & $31.8 \pm 0.75$ & $31.0 \pm 0.55$ \\
\hline First service conception rate (\%) & $20^{*}(2 / 10)$ & $80(8 / 10)$ \\
\hline
\end{tabular}

Significant at $\mathrm{P}<0.05$

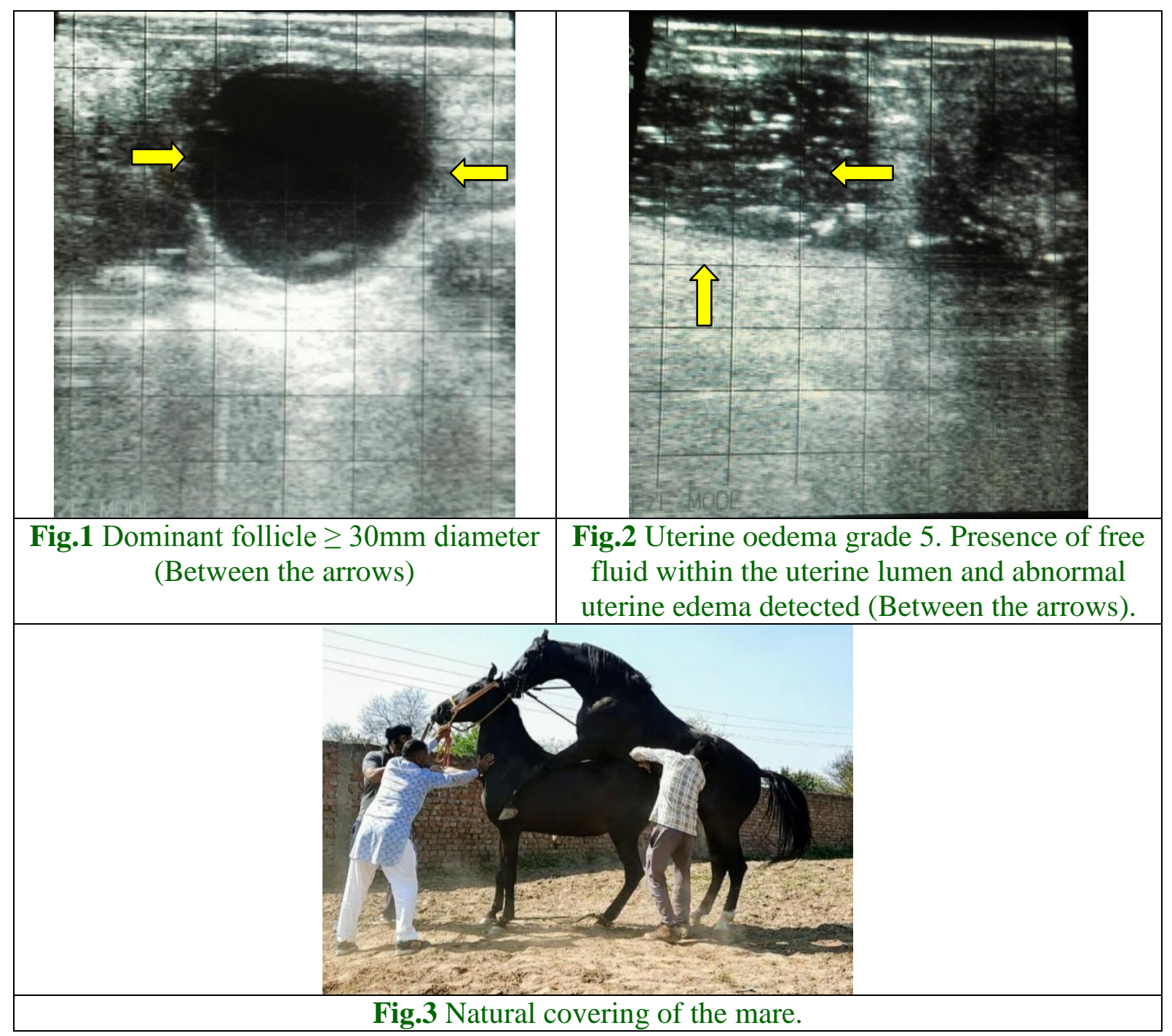

The presence of intrauterine fluid gives an accurate diagnosis of endometrial condition and is strongly associated with low pregnancy rates Maischberger et al., (2008), ParrillaHernandez et al., (2014). Uterine oedema and intrauterine fluid accumulation are important 
sonographic features of endometritis Leblance and Causey (2009). Intrauterine accumulation of fluid during foal heat has negative influence on pregnancy as it increases the chances of embryonic death in 18.2 percent of mares between days 12 to 45 of gestation Malschitzky et al., (2003). Rapid cleaning of uterus and involution is necessary to reestablish pregnancy which usually occurs around 30 days postpartum Macpherson (2012).

Considering the poor conception during foal heat many workers have attempted to breed the mares during second postpartum estrus if exhibited at around 30 days post foaling Nagy et al., (2003). Following $\mathrm{PGF}_{2 \alpha}$ administration in group II on day 28 postpartum, the estrus signs appeared within 36-48 hrs. Card (2011) also reported that the mares come to estrus within 3 days post prostaglandin induction, however, timing of ovulation may vary between 3-10 days following single prostaglandin therapy Sertich (2020). LOn day 28 postpartum in group II, uterus might have returned to its pre-foaling state in terms of both tissue health and size led to proper uterine involution. The natural breeding (Fig. 3) during induced heat yielded higher conception as compared to foal heat breeding which may be attributed to reduction in accumulation of intrauterine fluid and edema in postpartum mares.

\section{References}

Admin, H., 2016. Should I breed my mare on foal heat. Sporthorse database. P. O. Box 8110, Mauchline, United Kingdom.

Card, C., 2011. Hormonal management of mares.
Proceedings fetch DVM 360.conference, Kansascity, Baltimore, San Diego.

Leblanc, M.M, and Causey, R.C. 2009. Clinical and subclinical endometritis in the mares; both threats to fertility. Reproduction in domestic animals.44(3): 156-67

Macpherson, M., 2012. Breeding mares on foal heat. Proceedings $63^{\text {rd }}$ annual convention of American Association of Equine Practitioners. San Antonio, Texas, USA.

Maischberger, E., Irwin, J.A., Carrington, S.D and Duggan, V.E. 2008. Equine post breeding endometritis; A review. Irish veterinary journal. 61(3): 163

Malschitzky, E., Schilela, A., Mattos, G., Garbade, P., Gregory, R.M and Mattos, R.C. 2003. Intrauterine fluid accumulation during foal heat increase embryonic death. Pferdeheilkunde. 19(6): 646-649

McCue, P.M., 2010. Foal heat breeding. Equine Reproduction Labatory. Colorado State University, USA.

Nagy, P., Juhasz, J and Huszenicza, G. 2003. Physiology and Pathology of Equine postpartum period. Literature review and own experience. Magyar Allatorvosok Lapja. 125(3): 131-142

Parrilla-Hernandez, S., Ponthier, J., Franck, T.Y., Serteyn, D.D and Deleuze, S.C. 2014. High concentrations of myeloperoxidases in the equine uterus as an indicator of endometritis. Theriogenology. 81(7): 936-40

Rasmussen, C.D., Petersen, M.R., Bojesen, A.M., Pedersen, H.G., Lehn-Jensen, $\mathrm{H}$ and Christoffersen, M. 2015. Equine infectious endometritis - clinical and subclinical cases. Journal of Equine veterinary science.35(2): 95-104

Sertich, P.L., 2020. Reproductive cycles of horses. The merck Veterinary Manual. New balton center, School of veterinary medicine, University of Pennsylvania, USA.

\section{How to cite this article:}

Mahal, J. S., M. Honparkhe, Ajeet Kumar and Parladh Singh. 2020. Conception Rates Following Breeding at Foal Heat Versus Induced Heat in Postpartum Indigenous Mares. Int.J.Curr.Microbiol.App.Sci. 9(04): 1904-1907. doi: https://doi.org/10.20546/ijcmas.2020.904.225 